Biological and Clinical Sciences Research Journal

ISSN: 2708-2261

www.bcsrj.com

DOI: https://doi.org/10.54112/bcsri.v2021i1.52

Biol. Clin. Sci. Res. J., Volume, 2020: 52

MEDEYE

Original Research Article

\title{
GENETIC EVALUATION FOR MORPHOLOGICAL TRAITS OF CORIANDRUM SATIVUM GROWN UNDER SALT STRESS
}

\author{
AFTAB A, *HAIDER MA, ALI Q, MALIK A \\ Institute of Molecular Biology and Biotechnology, The University of Lahore, Lahore, Pakistan \\ Corresponding author email: maounh07@gmail.com
}

(Received, $11^{\text {th }}$ April 2020, Revised $25^{\text {th }}$ January 2021, Published $29^{\text {th }}$ January 2021)

\begin{abstract}
The Coriandrum is most important among the herb which is used as an ingredient in daily human food. It contains a good amount of antioxidants and health improving ingredients that save human body cells from diseases. It is very sensitive for abiotic environmental stress conditions involving drought, heat, and salt stress as important stress conditions. For this purpose, a study was planned to conduct in the greenhouse of the Institute of Molecular Biology and Biotechnology, University of Lahore to determine the effects of salt stress on Coriandrum seedling growth. For our study we have selected four Coriandrum varieties viz., GAMZE, EAGLE, SUPER XO, and PAK$O R G$. The results revealed that there were significant differences among the treatments of NaCl concentrations, Coriandrum genotypes, and the interactions among the Coriandrum genotypes and salt concentrations applied. The average Coriandrum seedling length was recorded as $23.021 \pm 1.2026 \mathrm{~cm}$ while root length was recorded as $22.0128 \pm 1.0027 \mathrm{~cm}$. The genotype GAMZE showed higher root and shoot length which indicated that GAMZE was a higher salt-tolerant genotype and may be used as a salt-tolerant genotype to improve yield per plant in Coriandrum. The genotype EAGLE has shown poor performance for all of the studied traits which indicated that it was a saltsensitive Coriandrum genotype. The genetic advance and heritability were found higher for all of the studied traits. The significant correlation between shoot length and root length indicated that the genotypes grow longer roots under stress conditions to increase the shoot length of plants while survive under stressful environmental conditions. The selection of Coriandrum genotype on the basis of root length and shoot length may be useful to improve slat stress tolerance in Coriandrum genotypes for higher seed and green plant biomass yield.
\end{abstract}

Keywords: Coriandrum sativum, salt stress, genetic advance, heritability, seedling traits, root length, shoot length

\section{Introduction}

Dhaniya consist of dried ripe fruit of Coriandrum sativum Linn Umbeliferae (Evans, 2002), a Slender, glabrous, branched, cultivated all over Pakistan, giving characteristic aroma when rubbed. It is annual herb originating from the Mediterranean (Mir, 1992; Rondon et al., 2011; Vaidya and Gogte, 2000). The whole plant and especially the unripe fruit, is characterized by a strong disagreeable odour, wherever the name coriander (from the Greek k'opis, a bug) (Gruenwalded, 2004). In Pakistan the Coriandrum is grown or cultivated around whole year times in each of the year as autumn as well as spring seasons of country. With an active involvement for multinationals in the country, the growing or cultivation of Coriandrum has been improved or increased as compared with previous years. However, the climatic as well as the soil conditions in Pakistan has been most responsive and adaptive for Coriandrum seed and green production however the yield is still very low in Pakistan as compared with other Coriandrum growing countries of the world (Aissaoui et al., 2008; Ali et al., 2008;
Bilal et al., 2020). The crop protection and it management plays an important role in the improvement of grain yield and production under every type of environmental conditions. The management inputs are included as the improved seed varieties, irrigation, the planting pattern, crop sowing times, the use of fertilizers and crop plant population play an effective and major role in enhancement of crop plant and grain yield under any type of environmental condition (Eguale et al., 2007; Handa and Kaul, 1996). The Coriandrum crop plant is generally cultivated or grown under the irrigated field conditions of Pakistan. The water has been shortening due to shortage or less of rain falls, the water has been becoming scarce throughout the whole country which is causing salt stress. The water limitations and salt stresses have also adverse effects on other crop plants like other crops (Kansal et al., 2011; Matasyoh et al., 2009).

The significant losses of Coriandrum seed yield have been projected because of drought which is increasing with the global climate changes in the major Coriandrum producing areas of the world. The

[Citation: Aftab, A., Haider, M.A., Ali, Q., Malik A. (2021). Genetic evaluation for morphological traits of Coriandrum sativum grown under slat stress. Biol. Clin. Sci. Res. J., 2021: 52. doi: https://doi.org/10.54112/bcsrj.v2021i1.52] 
majority of the Coriandrum has been grown under the irrigated conditions of Pakistan (Mir, 1992; Ramadan and Mörsel, 2002). The Coriandrum plant suffers due to salt and drought stress up to $40-80 \%$ in yield loss. The salt has been considered one of the major factors which affect plant growth as well as the seed yield of Coriandrum. There has been a need for recognizing a suitable and executive technique for Coriandrum cultivation which can resist salt and drought stress environmental conditions (Ramadan and Mörsel, 2002; Silva et al., 2011). The Coriandrum has higher water demands which can give higher grain production even when the water, mineral and other soil nutrients have become sufficient in amount and avail to plants easily, the Coriandrum plant is also very sensitive (Pharmacopoeia, 2005) for salt and water deficit of moisture stress environment along with other stress environments like cold, heat, salt and alkaline conditions (Pharmacopoeia, 2005; Saeed and Tariq, 2007).

\section{Materials and methods}

Coriandrum is herb plant which is grown throughout whole world for its use in food, salad and other herbal byproducts. Coriandrum is very sensitive to abiotic or environmental stress conditions involving drought, heat, cold and salt stress as important stress conditions. For this purpose a study was planned to conduct in greenhouse of IMBB (Institute of Molecular Biology and Biotechnology), The University of Lahore, Lahore to estimate effects of salt stress on Coriandrum seedling growth. For our study we have selected three Coriandrum varieties viz., GAMZE, EV-097Q, SUPER XO and PAKORG. Seed from selected Coriandrum genotype was used to grow in 54 pots, filled with $2 \mathrm{~kg}$ pure washed sand. The sand was mixed with $500 \mathrm{mg} / \mathrm{kg}$ of $\mathrm{NaCl}$ in each of the pot except of the control pots for Coriandrum sowing. The seed of each variety were sown in triplicate pots with all irrigation requirements in equal manners. To carry out our research work we have used following sets for treatment of $\mathrm{NaCl}$ : T0. Control or no any salt treatment, $\mathrm{T}_{1} 0.2 \mathrm{Molar} \mathrm{NaCl}$, $\mathrm{T}_{2}$ 0.4Molar $\mathrm{NaCl}, \mathrm{T}_{3}$ 0.6Molar $\mathrm{NaCl}, \mathrm{T}_{4}$ 0.8Molar $\mathrm{NaCl}$ and $\mathrm{T}_{5} 1 \mathrm{Molar} \mathrm{NaCl}$. The treatment of salt or $\mathrm{NaCl}$ was applied after the germination of Coriandrum seeds and data was recorded for various seedling traits. The treatment was applied and again data was recorded after one week of salt application. The data recorded for two times from two weeks was pooled to carried analysis of variance and all pairwaise comparisons for Coriandrum varieties and treatments of salt. Data was recorded for various morphological traits including, roots per plant, root length, shoot length, shoot water contents and root water contents. The recorded data which was statistically analyzed through using analysis of variance techniques through using SPSS23.1 software.

\section{Results and discussions}

The results form table 1 revealed that there was significant differences for all studied traits among the treatments of $\mathrm{NaCl}$ concentrations (0.2Molar, 0.4Molar, 0.6Molar, 0.8Molar and 1Molar) along with control and Coriandrum genotypes used for research evaluation and the interactions among the Coriandrum genotypes and salt concentrations applied. The results also indicated that there was lower coefficient of variation (ranging from $0.35 \%$ to $0.99 \%$ ) recorded for all studied traits of Coriandrum under effects of various salt concentrations which indicated that the consistency of results was higher and predications may be useful for selecting Coriandrum under salt stress to use as response variable. The heritability wa found higher for root water contents $(93.245 \%)$ followed by root length $(92.882 \%)$, shoot water contents $(90.234 \%)$, shoot length (89.2315) and roots per plant $(88.089 \%)$. The higher heritability indicated that the selection of Coriandrum genotypes may useful to produce hybrids or composite varieties of Coriandrum for improving yield under salt stress conditions. The genetic advance was found relative higher for all of the studied traits which revealed that the selection of Coriandrum genotypes may be useful to produce synthetic varieties for improved yield under slat stress conditions. The average length of shoot in Coriandrum genotypes was recorded as $23.021 \pm 1.2026 \mathrm{~cm}$ under all salt concentration applications. The higher shoot length under salt concentration indicated that the Coriandrum genotypes showed tolerance against salt stress and tends to improve plant growth and development even under salt stress environment (Rahman et al., 2009; Ramadan et al., 2003; Singletary, 2016). The results from all pairwise comparison revealed that there was higher shoot length of Coriandrum seedlings under the treatment of $0.6 \mathrm{Molar} \mathrm{NaCl}(25.140 \mathrm{~cm})$ followed by $0.2 \mathrm{Molar} \mathrm{NaCl}(24.08 \mathrm{~cm})$ and 0.4 Molar $\mathrm{NaCl}$ $(23.037 \mathrm{~cm})$ while lowest length of shoot in Coriandrum genotypes which was found under the application of 1 Molar $\mathrm{NaCl} \quad(21.173 \mathrm{~cm})$ concentration. The higher shoot length under lower $\mathrm{NaCl}$ concentrations indicated that there were litter effects due to salt applications on growth as well as development of seedlings while with the increase in the concentration of $\mathrm{NaCl}$ application the seedling length was decreased which showed the adverse

[Citation: Aftab, A., Haider, M.A., Ali, Q., Malik A. (2021). Genetic evaluation for morphological traits of Coriandrum sativum grown under slat stress. Biol. Clin. Sci. Res. J., 2021: 52. doi: https://doi.org/10.54112/bcsrj.v2021i1.52] 
effects of salt applications on Coriandrum seedling growth. The lowest under higher 1Molar $\mathrm{NaCl}$ concentration indicated that the application of higher concentration caused more damages in the seedling to reduce growth and development (Mandal and Mandal, 2015; Msaada et al., 2007; Ovais et al., 2018).

Table 1. Analysis of variance of Coriandrum traits morphological under different salt concentrations

\begin{tabular}{|c|c|c|c|c|c|c|}
\hline Source & DF & $\begin{array}{l}\text { Shoot } \\
\text { length }\end{array}$ & $\begin{array}{l}\text { Root } \\
\text { length }\end{array}$ & $\begin{array}{l}\text { Roots per } \\
\text { plant }\end{array}$ & $\begin{array}{l}\text { Shoot water } \\
\text { contents }\end{array}$ & Root water contents \\
\hline Replication & 1 & $11.4309 \mathrm{~ns}$ & $9.0828 \mathrm{~ns}$ & $9.00 \mathrm{~ns}$ & $10.0238 \mathrm{~ns}$ & $12.00 \mathrm{~ns}$ \\
\hline Genotypes & 3 & $3.0467 *$ & $7.6075^{*}$ & $22.6342 *$ & $33.4521 *$ & $3.8611 *$ \\
\hline Treatments & 5 & $22.8233 *$ & $25.9515^{*}$ & $27.9255^{*}$ & $45.0832 *$ & $21.7500^{*}$ \\
\hline $\begin{array}{l}\text { Genotypes } \times \\
\text { Treatment }\end{array}$ & 15 & $7.6033 *$ & $1.6475^{*}$ & $23.1908 *$ & $26.2421 *$ & $3.9278 *$ \\
\hline Error & 23 & 0.00002 & 0.00001 & 0.00001 & 0.0002 & 0.00001 \\
\hline Grand mean & & 23.021 & 22.0128 & 9.5617 & 84.905 & 79.508 \\
\hline Standard Error & & 1.2026 & 2.0135 & 0.3452 & 3.5012 & 3.0054 \\
\hline $\begin{array}{l}\text { Coefficient of } \\
\text { variation }\end{array}$ & & 0.82 & 0.62 & 0.99 & 0.50 & 0.35 \\
\hline $\begin{array}{l}\text { Heritability } \\
\left(\mathrm{h}^{2} \mathrm{~b} . \mathrm{s}\right)\end{array}$ & & 89.231 & 92.882 & 88.089 & 90.234 & 93.245 \\
\hline $\begin{array}{l}\text { Genetic } \\
\text { advance }\end{array}$ & & 18.237 & 13.254 & 17.204 & 16.242 & 18.254 \\
\hline
\end{tabular}

$*=$ significant at $5 \%$ probability level, $\mathrm{ns}=$ non-significant

Table 1a. All-Pairwise Comparisons Test of morphological traits under different salt treatments

\begin{tabular}{|c|c|c|c|c|c|}
\hline Treatments & Shoot length & Root length & Roots per plant & Shoot water contents & Root water contents \\
\hline $\mathrm{T}_{0}$ control & $21.207 \mathrm{D}$ & $21.380 \mathrm{D}$ & $9.390 \mathrm{~B}$ & $85.146 \mathrm{AB}$ & $79.393 \quad \mathrm{~B}$ \\
\hline $\mathrm{T}_{1}$ 0.2Molar $\mathrm{NaCl}$ & $24.080 \mathrm{~B}$ & $22.080 \mathrm{C}$ & $9.323 \mathrm{~B}$ & $85.104 \mathrm{AB}$ & $80.010 \mathrm{~A}$ \\
\hline $\mathrm{T}_{2}$ 0.4Molar $\mathrm{NaCl}$ & $23.037 \mathrm{C}$ & $19.800 \mathrm{~F}$ & $10.423 \mathrm{~A}$ & $84.551 \quad \mathrm{~B}$ & 79.173 В \\
\hline $\mathrm{T}_{3}$ 0.6Molar $\mathrm{NaCl}$ & $25.140 \mathrm{~A}$ & $24.933 \mathrm{~B}$ & $9.423 \mathrm{~B}$ & $85.443 \mathrm{~A}$ & $79.484 \quad \mathrm{~B}$ \\
\hline $\mathrm{T}_{4}$ 0.8Molar $\mathrm{NaCl}$ & 21.240D & $20.733 \mathrm{E}$ & $9.423 \mathrm{~B}$ & $84.621 \quad \mathrm{~B}$ & $79.520 \quad \mathrm{~B}$ \\
\hline $\mathrm{T}_{5}$ 1Molar $\mathrm{NaCl}$ & 21.173D & $26.727 \mathrm{~A}$ & $9.387 \quad \mathrm{~B}$ & 84.566 B & $79.469 \quad \mathrm{~B}$ \\
\hline
\end{tabular}

Table 1b: All-Pairwise Comparisons Test for Coriandrum genotypes under different salt treatments

\begin{tabular}{|c|c|c|c|c|c|}
\hline Genotypes & Shoot length & Root length & Roots per plant & Shoot water contents & Root water contents \\
\hline SUPER XO & $21.957 \mathrm{C}$ & $22.417 \quad \mathrm{C}$ & $9.4456 \mathrm{~B}$ & $85.624 \mathrm{~A}$ & $80.683 \mathrm{~A}$ \\
\hline PAK-ORG & 22.741 B & $222.593 \mathrm{~B}$ & $9.4939 \mathrm{~B}$ & 83.885 & 78.896 B \\
\hline GAMZE & $23.241 \mathrm{~A}$ & $22.817 \mathrm{~A}$ & $9.7456 \mathrm{~A}$ & $85.206 \mathrm{~B}$ & 78.946 B \\
\hline EAGLE & $20.13 \quad \mathrm{D}$ & $21.134 \quad \mathrm{D}$ & $8.8721 \mathrm{C}$ & $82.133 \mathrm{D}$ & $77.214 \mathrm{D}$ \\
\hline
\end{tabular}

The average length of root in Coriandrum genotypes was recorded as $22.0128 \pm 1.0027 \mathrm{~cm}$ under all salt concentration applications (Table 1). The higher length of root under salt concentration showed that Coriandrum or Coriandrum genotypes showed tolerance against salt stress and tends to improve plant growth and development even under salt stress environment (Gruenwalded, 2004; Ikeura and Kobayashi, 2015; Pandey et al., 2011). The results from all pairwise comparison revealed that there was higher root length of Coriandrum seedlings under the treatment of 1 Molar $\mathrm{NaCl}(26.727 \mathrm{~cm})$ followed by 0.6 Molar $\mathrm{NaCl}(24.933 \mathrm{~cm})$ and 0.2 Molar $\mathrm{NaCl}$ $(22.080 \mathrm{~cm})$ while lowest length of roots in Coriandrum genotypes was found under the application of 0.4 Molar $\mathrm{NaCl} \quad(19.800 \mathrm{~cm})$ concentration. The higher length of roots under high $\mathrm{NaCl}$ concentrations indicated that there were litter effectiveness due to salt applications on the growth and development of seedlings while with the decrease in the concentration of $\mathrm{NaCl}$ application the length of roots was decreased which showed negative effects due to salt applications on Coriandrum seedling growth (Table 1a). The lowest under 0.4 Molar $\mathrm{NaCl}$ concentration indicated that the application of lower concentration caused more damages in the seedling to reduce growth and development (Coşkuner and Karababa, 2007; Diederichsen, 1996; Eguale et al., 2007).

The average roots/plant of Coriandrum genotypes was recorded as $9.5617 \pm 0.3452$ under all salt concentration applications (Table 1). The higher number of roots per plant under salt concentration indicated that the Coriandrum genotypes showed tolerance against salt stress and tends to improve plant growth and development even under salt stress

[Citation: Aftab, A., Haider, M.A., Ali, Q., Malik A. (2021). Genetic evaluation for morphological traits of Coriandrum sativum grown under slat stress. Biol. Clin. Sci. Res. J., 2021: 52. doi: https://doi.org/10.54112/bcsrj.v2021i1.52] 
environment (Kansal et al., 2011; Laribi et al., 2015; Panngom et al., 2018). The results from all pairwise comparison revealed that there was higher number of roots per plant of Coriandrum seedlings under the treatment of $0.4 \mathrm{Molar} \mathrm{NaCl}(10.423)$ followed by 0.6 Molar $\mathrm{NaCl}$ (9.423) and 0.8 Molar $\mathrm{NaCl}(9.423)$ while lowest roots/plant of Coriandrum genotypes was found under the application of $0.2 \mathrm{Molar} \mathrm{NaCl}$ (9.323) concentration. The higher roots/plant of Coriandrum under high $\mathrm{NaCl}$ concentrations indicated that there were litter effects of salt applications on the growth and development of seedlings while with the decrease in the concentration of $\mathrm{NaCl}$ application the roots/plant of Coriandrum was decreased which showed the adverse effects of salt applications on Coriandrum seedling growth (Table 1a). The lowest under 0.2Molar $\mathrm{NaCl}$ concentration indicated that the application of lower concentration caused more damages in the seedling to reduce growth and development (Matloup et al., 2017; Rebey et al., 2019; Sankaranarayanan et al., 2012; Sen et al., 2008). The average shoot water content of Coriandrum genotypes was recorded as $84.905 \pm 3.5012 \%$ under all salt concentration applications. The higher shoot water content under salt concentration indicated that the Coriandrum genotypes showed tolerance against salt stress and tends to improve plant growth and development even under salt stress environment (Godara et al., 2014; Hnamte et al., 2013; Malhotra et al., 2006). The results from all pairwise comparison revealed that there was higher shoot water contents in Coriandrum seedlings under the treatment of 0.6 Molar $\mathrm{NaCl}$ $(85.443 \%)$ followed by control $(85.146 \%)$ and $0.2 \mathrm{Molar} \mathrm{NaCl}(85.104 \%)$ while lowest shoot water contents of Coriandrum genotypes was found under the application of 0.4 Molar $\mathrm{NaCl}$ treatment $(84.551 \%)$ concentration. The higher shoot water content under high $\mathrm{NaCl}$ concentrations indicated that there were litter effects for salt applications on the growth and development of seedlings while low $\mathrm{NaCl}$ treatment the root dry weight was decreased which showed the adverse effects of salt applications on Coriandrum seedling growth. The low $\mathrm{NaCl}$ treatment indicated that the application of low treatment caused more damages in the seedling to reduce growth and development (Rondon et al., 2011; Sahu et al., 2014).

The average root water content of Coriandrum genotypes was recorded as $79.508 \pm 3.0054 \%$ under all salt concentration applications (Table 1). The higher root water content under salt concentration indicated that the coriandrum genotypes showed tolerance against salt stress and tends to improve plant growth and development even under salt stress environment (Dadiga et al., 2015; Jamali, 2012; Khan and Parveen, 2018; Mehta et al., 2011; Singh, 2013). The results from all pairwise comparison revealed that there was higher root water contents in coriandrum seedlings under the treatment of $0.2 \mathrm{Molar} \mathrm{NaCl}$ $(80.010 \%)$ followed by 0.8 Molar $\mathrm{NaCl}(79.520 \%)$ while lowest root water contents of Coriandrum genotypes was found under the application of 0.4 Molar $\mathrm{NaCl}$ treatment $(79.173 \%)$ concentration (Table 1a). The higher root water content under low $\mathrm{NaCl}$ concentrations indicated that there were litter effects of salt applications on the growth and development of seedlings while high $\mathrm{NaCl}$ treatment the root dry weight was decreased which showed the adverse effects of salt applications on Coriandrum seedling growth. High $\mathrm{NaCl}$ treatment indicated that the application of high treatment caused more damages in the seedling to reduce growth and development (Abdollahi et al., 2016; Dash et al., 2019; Mohammadipour and Souri, 2019; Singh, 2015).

The results showed that the variety GAMZE showed higher roots per plant, root water contents, shoot water contents, root and shoot length which indicated that GAMZE was higher salt tolerant genotype and may be used as salt tolerant genotype to improve yield per plant in Coriandrum. The genotype EAGLE has shown poor performance for all of the studied traits which indicated that it was salt sensitive Coriandrum genotype (Table 1b).

Table 2. Survival percentage of Coriandrum genotypes under different salt treatments

\begin{tabular}{lllll}
\hline Treatments & GAMZE & EAGLE & PAK-ORG & SUPER XO \\
\hline $\mathrm{T}_{0}$ control & 100 & 100 & 100 & 100 \\
$\mathrm{~T}_{1}$ 0.2Molar $\mathrm{NaCl}$ & 89.34 & 78.43 & 81.23 & 82.35 \\
$\mathrm{~T}_{2}$ 0.4Molar $\mathrm{NaCl}$ & 83.85 & 72.35 & 80.90 & 80.25 \\
$\mathrm{~T}_{3}$ 0.6Molar $\mathrm{NaCl}$ & 81.20 & 70.23 & 82.45 & 78.54 \\
$\mathrm{~T}_{4}$ 0.8Molar $\mathrm{NaCl}$ & 78.09 & 67.98 & 78.82 & 79.32 \\
$\mathrm{~T}_{5}$ 1Molar $\mathrm{NaCl}$ & 79.04 & 62.20 & 77.09 & 78.23 \\
\hline
\end{tabular}

The results from table 2 indicated that the genotype GAMZE showed higher survival rate percentage under all of the salt stress conditions as compared with other genotypes while the genotype EAGLE

[Citation: Aftab, A., Haider, M.A., Ali, Q., Malik A. (2021). Genetic evaluation for morphological traits of Coriandrum sativum grown under slat stress. Biol. Clin. Sci. Res. J., 2021: 52. doi: https://doi.org/10.54112/bcsrj.v2021i1.52] 
showed lower survival rate. It was also found that the survival rate was decreased in all of the genotypes with increased in salt stress effects. The decrease in survival indicated that the salt stress caused harmful effects on Coriandrum genotypes while the genotype GAMZE showed relatively higher survival rate which revealed that it may be used as salt tolerance Coriandrum genotype (Mazhar et al., 2020; Shafique, 2020; Zubair et al., 2016). The results from table 3 indicated that there was a significant and positive correlation of shoot length with root length, roots per plant and shoot water contents. The significant correlation between shoot length and root length indicated that the genotypes grow longer roots under stress conditions to increase the shoot length of plants while survive under stressful environmental conditions. The selection of Coriandrum genotype on the basis of root length and shoot length may be useful to improve slat stress tolerance in Coriandrum genotypes for higher seed and green plant biomass yield (Ali et al., 2013; Ali et al., 2016; Ali et al., 2014).

Table 3. Correlation for morphological traits of Coriandrum genotypes under different salt treatments

\begin{tabular}{lllll}
\hline Traits & Shoot length & Root length & Roots per plant & Shoot water contents \\
\hline Root length & $0.4258^{*}$ & & & \\
Roots per plant & $0.3712^{*}$ & $0.5623^{*}$ & & \\
Shoot water contents & $0.4622 *$ & $-0.3482^{*}$ & 0.0023 & $0.5291^{*}$ \\
Root water contents & 0.2381 & $0.4526^{*}$ & $0.3284 *$ & \\
\hline
\end{tabular}

\section{Conflict of interest}

The authors declared absence of conflict of interest.

References

Abdollahi, F., Salehi, A., Shahabi, R., and Rahimi, A. (2016). Effect of different nitrogen sources on vegetative traits, grain yield and essential oil yield of coriander (Coriandrum sativum). Cercetari Agronomice in Moldova 49, 51-65.

Aissaoui, A., El-Hilaly, J., Israili, Z. H., and Lyoussi, B. (2008). Acute diuretic effect of continuous intravenous infusion of an aqueous extract of Coriandrum sativum L. in anesthetized rats. Journal of ethnopharmacology 115, 89-95.

Ali, Q., Ahsan, M., Ali, F., Aslam, M., Khan, N. H., Munzoor, M., Mustafa, H. S. B., and Muhammad, S. (2013). Heritability, heterosis and heterobeltiosis studies for morphological traits of maize (Zea mays L.) seedlings. Advancements in Life sciences $\mathbf{1}$.

Ali, Q., Ahsan, M., Kanwal, N., Ali, F., Ali, A., Ahmed, W., Ishfaq, M., and Saleem, M. (2016). Screening for drought tolerance: comparison of maize hybrids under water deficit condition. Advancements in Life Sciences 3, 51-58.

Ali, Q., Ali, A., Waseem, M., Muzaffar, A., Ahmad, S., Ali, S., Awan, M., Samiullah, T., Nasir, I., and Tayyab, H. (2014). Correlation analysis for morpho-physiological traits of maize (Zea mays L.). Life Science Journal 11, 9-13.

Ali, S. S., Kasoju, N., Luthra, A., Singh, A., Sharanabasava, H., Sahu, A., and Bora, U. (2008). Indian medicinal herbs as sources of antioxidants. Food research international 41, $1-15$.
Bilal, M., Nasir, I., Tabassum, B., Akrem, A., Ahmad, A., and Ali, Q. (2020). Cytotoxicity and in-vitro antiviral activity of lectin from Crocus vernus 1. against potato virus Y. Applied Ecology and Environmental Research 18, 1301-1315.

Coşkuner, Y., and Karababa, E. (2007). Physical properties of coriander seeds (Coriandrum sativum L.). Journal of Food Engineering 80, 408-416.

Dadiga, A., Kadwey, S., and Prajapati, S. (2015). Influences of organic and inorganic sources of nutrients on growth, yield attributed traits and yield economic of coriander (Coriandrum sativum L.) cv JD-1. Indian Journal of Agricultural Research 49, 577-580.

Dash, S. K., Pathak, M., Tripathy, L., and Barik, S. (2019). Studies on effect of integrated nutrient management on growth and yield attributes in radish (Raphanus sativus L.) and its residual effect in coriander (Coriandrum Sativum L.) in radish-coriander cropping sequence. Journal of Pharmacognosy and Phytochemistry 8, 319322.

Diederichsen, A. (1996). "Coriander: Coriandrum Sativum L," Bioversity International.

Eguale, T., Tilahun, G., Debella, A., Feleke, A., and Makonnen, E. (2007). In vitro and in vivo anthelmintic activity of crude extracts of Coriandrum sativum against Haemonchus contortus. Journal of Ethnopharmacology 110, 428-433.

Evans, W. (2002). Trease and Evans: Pharmacognocy. Fifteenth International Edition. Edinburgh, London, New York: WB Saunders.

[Citation: Aftab, A., Haider, M.A., Ali, Q., Malik A. (2021). Genetic evaluation for morphological traits of Coriandrum sativum grown under slat stress. Biol. Clin. Sci. Res. J., 2021: 52. doi: https://doi.org/10.54112/bcsrj.v2021i1.52] 
Godara, A., Gupta, U., Lal, G., and Singh, R. (2014). Influence of organic and inorganic source of fertilizers on growth, yield and economics of coriander (Coriandrum sativum L.). Int J Seed Spice 4, 77-80.

Gruenwalded, J. (2004). PDR-HM Physicians' desk reference for herbal medicine. Medical Economics. NJ 8, 378-84.

Handa, S., and Kaul, M. K. (1996). Supplement to cultivation and utilization of medicinal plants.

Hnamte, V., Chatterjee, R., and Tania, C. (2013). Growth, flowering, fruit setting and maturity behaviour of coriander (Coriandrum sativum L.) with organics including biofertilizers and inorganics. The bioscan 8, 791-793.

Ikeura, H., and Kobayashi, F. (2015). Antimicrobial and antifungal activity of volatile extracts of 10 herb species against Glomerella cingulata. Journal of Agricultural Science 7, 77.

Jamali, M. M. (2012). Investigate the effect of drought stress and different amount of chemical fertilizers on some physiological characteristics of coriander (Coriandrum sativum L.). International journal of Agronomy and Plant Production 3, 585-589.

Kansal, L., Sharma, V., Sharma, A., Lodi, S., and Sharma, S. (2011). Protective role of Coriandrum sativum (coriander) extracts against lead nitrate induced oxidative stress and tissue damage in the liver and kidney in male mice. Int J Appl Biol Pharm Technol 2, 65-83.

Khan, M. R., and Parveen, G. (2018). Supplementing biocontrol agents with botanicals improved growth and yield of coriander (Coriandrum sativum L.) infected with Protomyces macrosporus Unger. Current Plant Biology 15, 44-50.

Laribi, B., Kouki, K., M'Hamdi, M., and Bettaieb, T. (2015). Coriander (Coriandrum sativum L.) and its bioactive constituents. Fitoterapia 103, 9-26.

Malhotra, S., Vashishtha, B., and Apparao, V. (2006). Influence of nitrogen, Azospirillum sp. and farmyard manure on growth, yield and inci-dence of stem gall disease in coriander (Coriandrum sativum L.). Journal of Spices and Aromatic Crops 15, 115-117.

Mandal, S., and Mandal, M. (2015). Coriander (Coriandrum sativum L.) essential oil: Chemistry and biological activity. Asian Pacific Journal of Tropical Biomedicine 5, 421-428.
Matasyoh, J., Maiyo, Z., Ngure, R., and Chepkorir, R. (2009). Chemical composition and antimicrobial activity of the essential oil of Coriandrum sativum. Food Chemistry 113, 526-529.

Matloup, O., Abd El Tawab, A., Hassan, A., Hadhoud, F., Khattab, M., Khalel, M., Sallam, S., and Kholif, A. (2017). Performance of lactating Friesian cows fed a diet supplemented with coriander oil: feed intake, nutrient digestibility, ruminal fermentation, blood chemistry, and milk production. Animal Feed Science and Technology 226, 88-97.

Mazhar, T., Ali, Q., and Malik, M. (2020). Effects of salt and drought stress on growth traits of Zea mays seedlings. Life Science Journal 17.

Mehta, R., Anwer, M., Malhotra, S., Lal, G., Aishwath, O., Meena, S., Kant, K., and Khan, M. (2011). Growth and yield of coriander (Coriandrum sativum L)) as affected by sheep manure, vermi-compost and bio-fertilizer. International J. Seed Spices 1, 22-28.

Mir, H. (1992). Coriandrum sativum. Application of plants in prevention and treatment of illnesses. Persian 1, 257-52.

Mohammadipour, N., and Souri, M. K. (2019). Beneficial effects of glycine on growth and leaf nutrient concentrations of coriander (Coriandrum sativum) plants. Journal of Plant Nutrition 42, 1637-1644.

Msaada, K., Hosni, K., Taarit, M. B., Chahed, T., Kchouk, M. E., and Marzouk, B. (2007). Changes on essential oil composition of coriander (Coriandrum sativum L.) fruits during three stages of maturity. Food Chemistry 102, 1131-1134.

Ovais, M., Zia, N., Ahmad, I., Khalil, A. T., Raza, A., Ayaz, M., Sadiq, A., Ullah, F., and Shinwari, Z. K. (2018). Phyto-therapeutic and nanomedicinal approaches to cure alzheimer's disease: present status and future opportunities. Frontiers in aging neuroscience 10, 284.

Pandey, A., Bigoniya, P., Raj, V., and Patel, K. (2011). Pharmacological screening of Coriandrum sativum Linn. for hepatoprotective activity. Journal of Pharmacy and Bioallied sciences 3, 435.

Panngom, K., Chuesaard, T., Tamchan, N., Jiwchan, T., Srikongsritong, K., and Park, G. (2018). Comparative assessment for the effects of reactive species on seed germination, growth and metabolisms of vegetables. Scientia Horticulturae 227, 85-91.

[Citation: Aftab, A., Haider, M.A., Ali, Q., Malik A. (2021). Genetic evaluation for morphological traits of Coriandrum sativum grown under slat stress. Biol. Clin. Sci. Res. J., 2021: 52. doi: https://doi.org/10.54112/bcsrj.v2021i1.52] 
Pharmacopoeia, B. (2005). The Stationary Office on behalf of the Medicines and Healthcare products Regulatory Agency (MHRA), London, Vol-I. Ph. Eur. monograph 1002.

Rahman, M. A., Rahman, I., and Hasegawa, H. (2009). Dietary intake of potentially toxic elements from vegetables. Fruit and vegetable consumption and health.

Ramadan, M., and Mörsel, J.-T. (2002). Oil composition of coriander (Coriandrum sativum L.) fruit-seeds. European Food Research and Technology 215, 204-209.

Ramadan, M. F., Kroh, L. W., and Mörsel, J.-T. (2003). Radical scavenging activity of black cumin (Nigella sativa L.), coriander (Coriandrum sativum L.), and niger (Guizotia abyssinica Cass.) crude seed oils and oil fractions. Journal of agricultural and food chemistry 51, 6961-6969.

Rebey, I. B., Wannes, W. A., Kaab, S. B., Bourgou, S., Tounsi, M. S., Ksouri, R., and Fauconnier, M. L. (2019). Bioactive compounds and antioxidant activity of Pimpinella anisum L. accessions at different ripening stages. Scientia horticulturae 246, 453-461.

Rondon, F. C., Bevilaqua, C. M., Accioly, M. P., Morais, S. M., Andrade-Junior, H. F., Machado, L. K., Cardoso, R. P., Almeida, C. A., Queiroz-Junior, E. M., and Rodrigues, A. C. M. (2011). In vitro effect of Aloe vera, Coriandrum sativum and Ricinus communis fractions on Leishmania infantum and on murine monocytic cells. Veterinary Parasitology 178, 235-240.

Saeed, S., and Tariq, P. (2007). Antimicrobial activities of Emblica officinalis and Coriandrum sativum against gram positive bacteria and Candida albicans. Pak. J. Bot 39, 913-917.

Sahu, R. L., Sahu, H., and Kumar, S. (2014). Effect of application of inorganic fertilizers and biofertilizers on growth components and yield traits of coriander (Coriandrum sativum L.). Progressive Horticulture 46, 102-106.

\section{(c) (1) 8)}

Open Access This article is licensed under a Creative Commons Attribution 4.0 International License, which permits use, sharing, adaptation, distribution and reproduction in any medium or format, as long as you give appropriate credit to the original author(s) and the source, provide a link to the Creative Commons licence, and indicate if changes were made. The images or other third
Sankaranarayanan, K., Nalayini, P., and Praharaj, C. (2012). Multi-tier cropping system to enhance resource utilization, profitablity and sustainablity of $\mathrm{Bt}$ cotton (Gossypium hirsutum) production system. Indian Journal of Agricultural Sciences 82, 1044-50.

Sen, G., Mukhopadhyay, S., Ray, M., and Biswas, T. (2008). Quercetin interferes with iron metabolism in Leishmania donovani and targets ribonucleotide reductase to exert leishmanicidal activity. Journal of Antimicrobial Chemotherapy 61, 1066-1075.

Shafique, F. A., Q Yasin, G Ahmad, S Shafeeq, T Zaheer, A Malik A (2020). Heavy metal toxicity and it's Physio-Biochemical effects on maize (Zea mays L.). Plant Cell Biotechnology and Molecular Biology 21, 94-102.

Silva, F., Ferreira, S., Duarte, A., Mendonca, D. I., and Domingues, F. C. (2011). Antifungal activity of Coriandrum sativum essential oil, its mode of action against Candida species and potential synergism with amphotericin B. Phytomedicine 19, 42-47.

Singh, S. (2013). Effect of bio-fertilizer azospirillum on growth and yield parameters of coriander (Coriandrum sativum L.) cv. Pant haritima. Vegetable Science 40, 77-79.

Singh, S. (2015). Effect of organic manures on growth, yield and economics of coriander (Coriandrum sativum L.). Journal of Ecofriendly Agriculture 10, 124-127.

Singletary, K. (2016). Coriander: Overview of potential health benefits. Nutrition today 51, 151-161.

Vaidya, V., and Gogte, M. (2000). Ayurvedic Pharmacology \& Therapeutic uses of medicinal plants. Swami Prakashananda ayurvedic research center, Mumbai, 656-657.

Zubair, M., Shakir, M., Ali, Q., Rani, N., Fatima, N., Farooq, S., Shafiq, S., Kanwal, N., Ali, F., and Nasir, I. A. (2016). Rhizobacteria and phytoremediation of heavy metals. Environmental Technology Reviews 5, 112119.

party material in this article are included in the article's Creative Commons licence, unless indicated otherwise in a credit line to the material. If material is not included in the article's Creative Commons licence and your intended use is not permitted by statutory regulation or exceeds the permitted use, you will need to obtain permission directly from the copyright holder. To view a copy of this licence, visit http://creativecommons.org/licenses/by/4.0/.

(c) The Author(s) 2021

[Citation: Aftab, A., Haider, M.A., Ali, Q., Malik A. (2021). Genetic evaluation for morphological traits of Coriandrum sativum grown under slat stress. Biol. Clin. Sci. Res. J., 2021: 52. doi: https://doi.org/10.54112/bcsrj.v2021i1.52] 